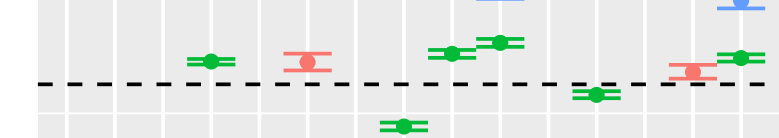

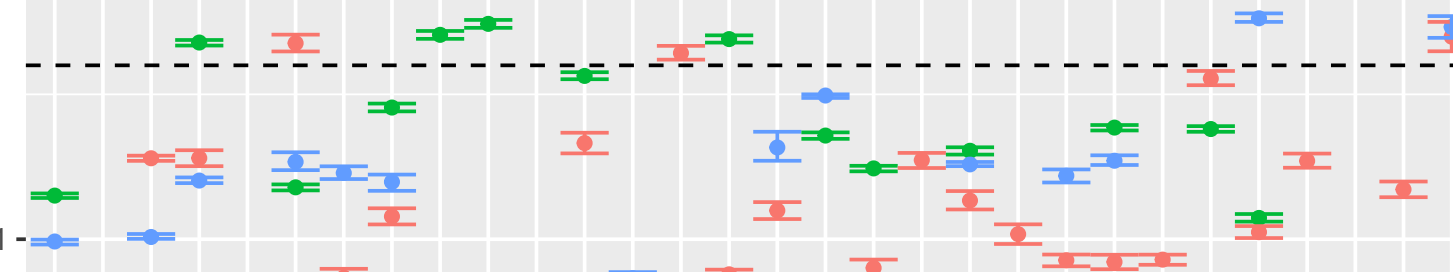

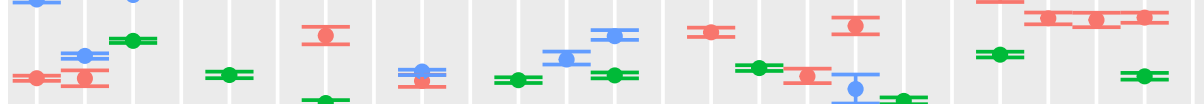

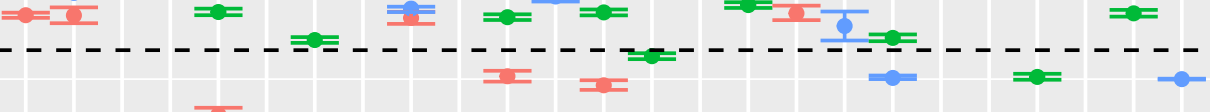

$=$

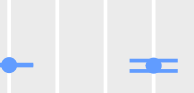

$\overline{n-1}$

$=-$

$=$ $\supset$
D
$\mathscr{W}$
$\widetilde{1}$

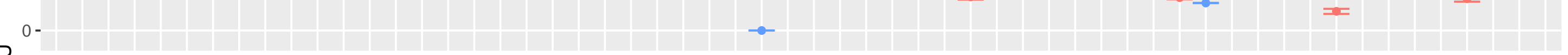
$4-$

\section{Cap gene}

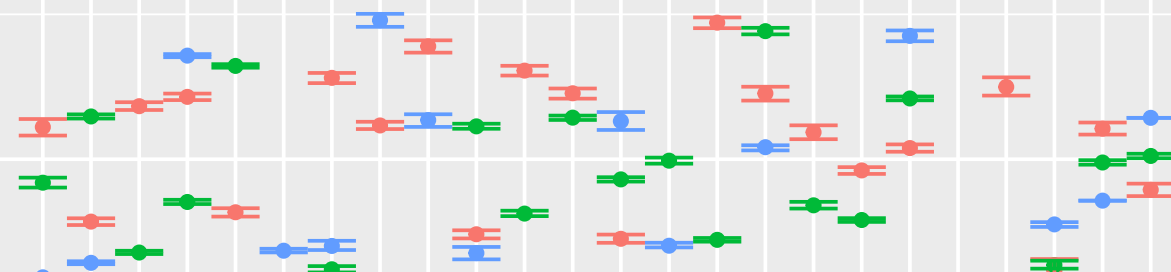

$3-$

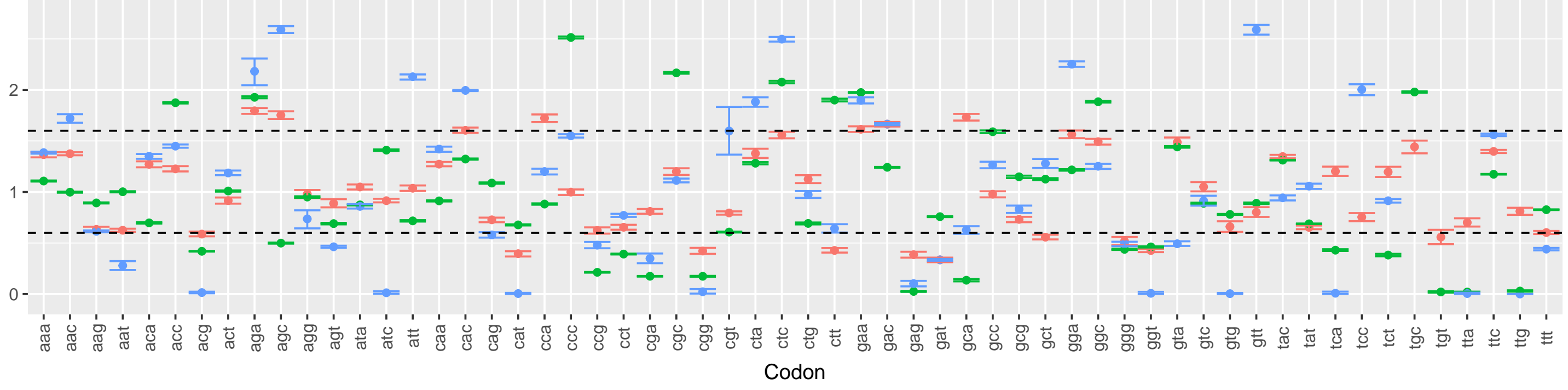

